\title{
Sustainable Repairing and Improvement of Concrete Properties Using Bacterial Consortium Isolated From Egypt
}

Hala H. A. Mahmoud

Engineer tutor, Civil Engineering, Mattaria institute, High Ministry of Education, Cairo, Egypt, Mohamed H. A. Kalaba

Lecturer of applied microbiology, Botany and microbiology Department, Faculty of Science (Boys), AlAzhar University, Cairo- Egypt.

Gamal M.E. El-Sherbiny ( $\nabla$ gamalelsherbiny1970@yahoo.com )

Al-Azhar University Faculty Science Microbiology Department https://orcid.org/0000-0003-3968-0536

Abdelzaher E. A. Mostafa

Professor, Civil Engineering, Mattaria School of Engineering, Helwan University, Cairo, Egypt,

Mohamed E. A. Ouf

Professor, Civil Engineering, Mattaria School of Engineering, Helwan University, Cairo, Egypt,

Engineering, Mattaria School of Engineering, Helwan University, Cairo, Egypt,

\section{Waleed M. F. Tawhed}

Assistant Professor, Properties and Strength of Materials Department, Mattaria School of Engineering, Helwan University, Cairo, Egypt.

\section{Research}

Keywords: Sustainable repairing, bacterial consortium, cracks, concrete, Bacillus flexus Bacillus haynesii

Posted Date: July 15th, 2021

DOl: https://doi.org/10.21203/rs.3.rs-688731/v1

License: (c) (i) This work is licensed under a Creative Commons Attribution 4.0 International License. Read Full License 


\title{
Sustainable repairing and improvement of concrete properties using bacterial
} consortium isolated from Egypt

\author{
Hala. H. A. Mahmoud', Mohamed. H. A. Kalaba ${ }^{2}$, Gamal. M. E. El-Sherbiny ${ }^{2}$, Abdelzaher.
} E. A. Mostafa ${ }^{3}$, Mohamed. E. A. Ouf ${ }^{3}$, Waleed. M. F. Tawhed ${ }^{3}$

${ }^{1}$ Civil Engineering, Mattaria institute, High Ministry of Education, Cairo, Egypt,

${ }^{2}$ Botany and Microbiology Department, Faculty of Science (Boys), Al-Azhar University, Cairo- Egypt. ${ }^{3}$ Civil Engineering, Mattaria School of Engineering, Helwan University, Cairo, Egypt,

\section{Corresponding author}

Prof. / Gamal M. El-sherbiny

Professor of Medical Microbiology, Botany and Microbiology Dept. Faculty of Science, AlAzhar University Cairo Egypt.

E-mail: gamalelsherbiny1970@azhar.edu.eg or gamalelsherbiny1970@yahoo.com

Tel+201064665699 ORCID: 0000-0003-3968-0536

\begin{abstract}
The small cracks in concrete constructions are inevitable due to deterioration during their service life throughout different load combination factors. In this study, we aimed to isolate, identify, and construct a bacterial consortium able to heal small cracks of concrete and enhance the different properties of concrete. Six isolates of bacillus, endospore-forming bacteria were isolated. There are only three isolates out of the six coded as NW-1, MK and NW-9 were showed the ability to produce urease enzyme and able to grow at $60^{\circ} \mathrm{C}$ with optimum growth at a temperature of $40^{\circ} \mathrm{C}$. These isolates were survived in high $\mathrm{pH}$, where isolate $\mathrm{NW}-1$ was tolerated $\mathrm{pH}$ up to 11 with optimum growth at 10 while the isolates NW-9 and MK showed growth at pH 12 with an ideal growth at $10 . \mathrm{CaCO}_{3}$ production was observed by the three bacterial isolates whether in pure or mixed cultures (bacterial consortium) but the consortium consisting of MK and NW-9 was significantly the highest in productivity among them. Therefore, these two isolates were identified using 16s as Bacillus flexus MK-FYT-3 and Bacillus haynesii MK-NW-9 and deposited to GenBank under accession numbers MN965692 and MN965693 respectively. The effect of bacteria on some properties of concrete was studied, and the results showed that the compressive and tensile strengths of bio-concrete specimens were significantly increased by 31.29, $29 \%$ after 7 days and 36.3, $39 \%$ after 28 days of curing compared to control specimens. The results of permeability indicated that the bio-concrete specimens significantly showed less permeability than the control
\end{abstract}


specimens by $21.1,23.1 \%$ after 7 and 28 of curing, respectively. To determine the concrete density,

35 Ultrasonic Pulse Velocity (UPV) test was performed, and the bio-concrete specimens gave higher values than control specimens by 26 and $20 \%$ after curing for 7 and 28 days, respectively. Also, surface healing of concrete was observed visually, the bio-concrete showed white precipitates around and inside the cracks after 7 days, which led to almost complete sealing of concrete after 28 days of curing, while the control samples were showed only very slight deposits on the surface and away from the cracks. The micro-analysis of concrete samples using SEM and XRD were done. It was found that the bio-concrete specimens showed crystalline precipitate with different shapes under SEM, while no such deposits appeared in the control specimens. On the other hand, the XRD profile was explained the characteristic peaks of calcium carbonate in both the bioconcrete and the control specimens, but the peak intensity was higher in the bio-concrete than the control specimens. This reflects the effectiveness of bacterial consortium in repairing and preventing the concrete cracks from spreading in addition to improving the various properties of concrete leading to increasing its life and sustainability.

Keywords: Sustainable repairing, bacterial consortium, cracks, concrete, Bacillus flexus Bacillus haynesii

\section{Introduction}

Concrete is a very widespread and inexpensive material utilized in construction because of the availability of its components such as cement, aggregate, and sand (Vashisht et al., 2018). durability, versatility, accessibility, matching with reinforcement bar, fireplace tolerance, low price, simple production, and consequently the capability of casting in the desired shape are amongst the main features of the concrete. These distinctive options led to huge usage of concrete in the construction of different structures like buildings, dams, storing tanks, industrial plants, and transport connectivity (Seifan et al., 2019). Despite the advantages of concrete, it tends to form cracks permitting destructive substances to attack the reinforcing steel or the cementitious matrix itself. Cracks are a major reason for concrete deterioration and hence decrease in its durability (Ganesh et al., 2019). Cracks are often produced in each soft and hard status. Formwork movement, plastic settlement, and plastic shrinkage due to the fast lack of water from the surface of concrete bring about crack creation at some stage in the plastic state. while crack formation in a hardened state may occur due to other factors as climate change, dry up shrinkage, error in style, heat 
pressure, chemicals attack, external load, and regular overload. furthermore, concrete structures suffer from moderately low ductileness and tensile force (Seifan et al., 2016). These finally decrease the lifetime of a building that is made with these materials due to cracks in concrete (Basha et al., 2019). To overcome this deterioration, several methods have been carried out to treat the resulted cracks and adjust the pore structure of concrete. Most of the treatments have been focused on the outside masking of cracks by using different materials such as silanes, acrylics, epoxy, waxes, and chlorinated rubbers (Nain et al., 2018). But the concrete has a weak attachment with these coating agents which are subject to deterioration and distortion with age and limits its efficiency and performance. These methods cannot block the pore networks and fill the interior porosities (Seifan et al., 2019). In addition, they are expensive, reduce aesthetics, are laborintensive, and affect the environment (Pungrasmi et al., 2019). Unlike passive treatments, the active treatment (self-healing techniques) be able to work through various environments with no human intervention and regardless of the location of the defect. This type of concrete contains specially developed additives that can instantly activate upon crack development and closing the crack (Van Mullem et al., 2020). A self-healing in the concrete mixes may be occurred by three major approaches: (i) Autogenic healing, which is the natural cracks treatment process occurred by hydration of unwetted cementitious particles or transformation of solubilized calcium hydroxide into insolubilized carbonate. But the practical means to progress autogenic healing is to decrease the water to cement (w/c) ratio. On the other hand, rising cement part to lower w/c ratio harms shrinkage and workability and requests more cement production. (ii) Encapsulation of polymeric material, this method can fill the cracks by converting the sealing material to foam in the occurrence of water. Though the release of sealing substances from the hollow fibers embedded within the concrete mixture can seal the cracks, these substances don't act like concrete structures in several circumstances and, in certain situations, lead to crack expansion. Additionally, this technology needs capsules that can be blended along with concrete easily and can persist inside a concrete mixture. These capsules should keep the filling factor for a prolonged period and should not affect the mechanical characters and workability of concrete ( Al-Tabbaa et al., 2018; De Belie et al., 2018). These needs make the encapsulation technique difficult to commercially apply in the concrete self-healing (Tan et al., 2020). (iii) Microbial calcium carbonate precipitation. It can be achieved by inserting appropriate bacterial spores inside the mixture of concrete plus nutrients to stimulate bacterial growth. By taking place of the crack, water, and oxygen entered, and at this 
point, the bacterial spores develop into active vegetative cells which decompose the available nutrient changing some of the environmental conditions such as $\mathrm{pH}$. By the presence of dissolved inorganic carbon (DIC) and $\mathrm{Ca}^{2+}$ ions the bacteria assist and speed up the formation of calcium carbonate, generally as calcite but sometimes as vaterite within cracks. Calcium carbonate production by microorganism is considered an ideal method for processing and present an efficient sealing; compatibility from a healing agent with the concrete matrix; long shelf life; ability to treat cracks repeatedly for an unlimited number of times and eco-friendly viability ( Silvab et al., 2020). Although this new technology has possible application value, there are yet some challenges that need to be resolved before large-scale application. The main problem is to maintain the viability of bacteria in the matrix of concrete, where the elevated $\mathrm{pH}$ condition and the shear force generated by the mixing will negatively affect the performance of the bio-concrete. Therefore, the present study was aimed to isolate endospore-forming, alkalophilic, and thermotolerant bacterial isolates that can produce calcium carbonate. Moreover, mixing of bacterial isolates spores together to form an artificial bacterial consortium, determination of their ability to deposit calcium carbonate in the cracks of concrete autogenously, and enhance the characteristics of concrete.

\section{1. Sediment sampling}

113 Sediment samples were collected from Elhamra lake, Wadi Elnatrun region, Albohayra

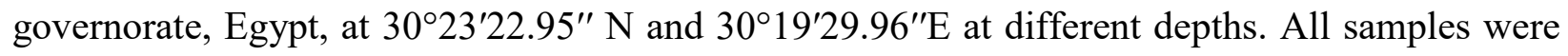

115 mixed and considered as only one sample.

\section{2. Isolation of endospore-forming bacteria}

117 Ten grams of sediment sample were suspended in $90 \mathrm{ml}$ of sterile $0.85 \%$ saline solution. In a water 118 bath, the sediment suspension was warmed at $80^{\circ} \mathrm{C}$ for 30 minutes. Then, $1 \mathrm{ml}$ of the previously 119 prepared sediment suspension was serially diluted up to $10^{5}$ and the $100-\mu 1$ suspension was spread 120 on nutrient agar (NA) plates (Sarkar et al., 2015). The pH of this medium was adjusted at 8 and 121 the inoculated NA plates were incubated at $40{ }^{\circ} \mathrm{C}$ for 2 days. The bacterial colonies that appeared 122 with different cultural features were selected and restreaked again on the same medium. These 123 bacteria were stained with Gram stain and checked for endospore formation according to (Chahal 124 et al., 2011; Kim et al., 2016)

\section{$125 \quad$ 2.1.Tolerance to alkaline $\mathrm{pH}$ and high temperature}


Each bacterial isolate was inoculated $(0.1 \mathrm{ml}$ of overnight broth culture $(O D 620 \mathrm{~nm}=0.8)$ in nutrient broth at different $\mathrm{pH}(7-12)$ using $\mathrm{NaOH}$ or $\mathrm{HCl}(1.0 \mathrm{~mol} / \mathrm{l})$ and incubated at $40^{\circ} \mathrm{C}$ in an incubator shaker at $150 \mathrm{rpm}$ for $24 \mathrm{~h}$. For determination of the temperature profile of the bacterial isolates, each isolate was cultured in nutrient broth at $\mathrm{pH} 8$ and incubated at 20,40 , and $60{ }^{\circ} \mathrm{C}$ in an incubator shaker at $150 \mathrm{rpm}$ for $24 \mathrm{~h}$. After incubation, the optical density was measured at wavelength $610 \mathrm{~nm}$ (UNICO 2100 UV Visible Spectrophotometer, Dickinson, Texas, USA) to check bacterial growth (Moghannem et al., 2015).

\subsection{Qualitative urease assay}

Urea agar plates ((g/l); urea, 20.0; $\mathrm{NaCl}$, 5.0; peptone, 1.0; glucose, 1.0; $\mathrm{KH}_{2} \mathrm{PO}_{4}, 2.0$; phenol red, 0.012 and agar, 15.0; ( $\mathrm{pH}$ 6.5) were prepared, inoculated with the selected bacterial isolates (OD $620 \mathrm{~nm}=0.8)$ and incubated at $37^{\circ} \mathrm{C}$ for 3-5 days. The plates were investigated to observe any change in the medium color from yellow to pink revealing urease positive action (Vashisht et al., 2018).

\subsection{Antagonistic activity of the tested isolates}

The antagonistic activity of the bacterial isolates was tested by the agar diffusion method. It was grown on nutrient agar media and the plates were incubated at $40^{\circ} \mathrm{C}$ for 3 days. After incubation, agar plugs $(6 \mathrm{~mm})$ were cut from these cultures with a sterile cork borer. The agar plugs of each two bacterial isolates were transferred to the surface of nutrient agar plates previously inoculated with the third bacterial isolate. The plates were then kept in a refrigerator at $4^{\circ} \mathrm{C}$ for $2 \mathrm{~h}$. to allow the diffusion of the metabolites into the medium then, all plates were incubated at $40^{\circ} \mathrm{C}$ for $24 \mathrm{~h}$. After incubation, the antagonistic activities of the tested plugs were determined by observation of the inhibition zones around the agar plug (Messaoudi et al., 2015).

\section{Calcium carbonate precipitation in broth culture and acid fizz tests}

The isolates were tested for $\mathrm{CaCO}_{3}$ precipitation in broth media. Briefly, in conical flasks, $30 \mathrm{ml}$ of sterile nutrient broth -urea- calcium (NB-U-Ca) medium (Dhami et al., 2016) were inoculated with $2 \%$ inoculum (Whether the isolates are pure or mixed culture (bacterial consortium) at equal ratios, the final OD of inoculum $=0.8$ at $620 \mathrm{~nm}$ ). The inoculated flasks as well as the control medium (without bacteria) was incubated under shaking conditions for 7 days at $150 \mathrm{rpm}$ and 40 -C. After incubation time, the conical flasks were centrifuged at $5000 \mathrm{rpm}$ for half-hour. Then the supernatant was collected, and the calcium carbonate formation was tested by adding 2 drops of $10 \% \mathrm{HCl}$; the formation of bubbles indicated $\mathrm{CO}_{2}$ gas generation and subsequently $\mathrm{CaCO}_{3}$ 
production ( Basha et al., 2018). On the other part, the precipitated $\mathrm{CaCO}_{3}$ of each culture was resuspended in a little amount of distilled water and collected on preweighed filter paper and dried at $80{ }^{\circ} \mathrm{C}$ for $24 \mathrm{~h}$. and subsequently weighed. The weight of formed $\mathrm{CaCO}_{3}$ (Wc) was calculated from the following equation:

$$
\mathrm{Wc}=\mathrm{Wfc}-\mathrm{Wf}
$$

where (Wfc) is the weight of filter paper containing precipitant, and (Wf) is the weight of empty filter paper.

\section{Molecular characterization of potential bacterial isolates}

Genomic DNA of each bacterial isolate was extracted from $50 \mathrm{ml}$ of liquid bacterial culture using the Gene Jet genomic DNA extraction kit (Thermo K0721) according to the manufacturer's instructions. Amplification of the $16 \mathrm{~S}$ ribosomal DNA of the selected isolates was carried out using the primers Bact27f (5'-GTTTGATCCTGGCTCAG-3') and 1492r (5'- CGGCTA CCTTGT TACGAC-3') by polymerase chain reaction (PCR) according to (Altschul et al.,1990)After that, the products of PCR were sequenced bi-directionally by using forward, reverse, and internal primers (27 f and 1492 r) with ABI 3730 l× DNA sequencer (GATC Biotech, Konstanz, Germany). The obtained sequence of each isolate was blasted on the GenBank to detect and compare the similarity of the isolates with the available sequences on the GenBank database.

\section{Cultivation of bacteria and preparation of bacterial spores}

The selected bacterial isolates for this study were cultivated on nutrient broth with initial pH10 and incubated for $48 \mathrm{~h}$. on a rotary shaker at $120 \mathrm{rpm}$ and $40{ }^{\circ} \mathrm{C}$. Preparation of bacterial spores was performed according to (Xu et al., 2019) with small modification as follows: at $5000 \mathrm{rpm}$, the bacterial culture of each isolate was centrifugated for $30 \mathrm{~min}$. The supernatant was discarded, and the residual bacterial pellets were re-mixed in sterile saline solution $(\mathrm{NaCl}, 8.5 \mathrm{~g} / \mathrm{L})$. The bacterial suspension was left in an incubator for 7 days at $40{ }^{\circ} \mathrm{C}$, meanwhile, the bacteria are in a state of starvation. Later, almost all vegetative cells became spores, and this was checked by microscopic examination of these suspensions as previously mentioned in the part of the endospore investigation. After that, $1 \mathrm{ml}$ of the spore suspension of each bacterial isolate was serially diluted $\left(10^{-1}-10^{-9}\right)$ in test tubes under aseptic conditions. To achieve homogeneity, test tubes were subjected to vertexing at $200 \mathrm{rpm}$ for two minutes. Then $0.1 \mathrm{ml}$ of each dilution was plated and spread onto alkaline ( $\mathrm{pH} 10)$ nutrient agar plates and incubated overnight at $40^{\circ} \mathrm{C}$. After incubation time, the growing bacterial colonies in these plates were counted as CFU/ml. According to this 
188

189

190

191

192

193

194

195

196

197

198

199

200

201

202

203

204

205

206

207

208

209

210

211

212

213

214

215

216

217

218

count, the concentration of spores of each bacterial isolate was adjusted to be $\sim 10^{6} \mathrm{CFU} / \mathrm{ml}$ and stored at $4{ }^{\circ} \mathrm{C}$.

\section{Preparation of mortar sample}

\subsection{Concrete Materials}

The composition of concrete mixes was characterized by the high content of Ordinary Portland cement aiming at the high compactness of the matrix. Portland cement CEM I, 52.5 N, containing 95\% of clinker and 5\% limestone was used. Locally available sand that passes via a sieve with pores $4.75 \mathrm{~mm}$ and corresponding to zone II of Egyptian standard specifications (ESS) 1109/2002 was used. Dolomite of maximum size $20 \mathrm{~mm}$ conforming to ESS 1109/2002 was used as coarse aggregates (Code, 2007). The specific gravity of the coarse and fine aggregates was determined to be 2.7 and 2.6 respectively.

\subsection{Mix Design and preparation of concrete Specimens}

Concrete specimens were designed according to ESS and the American Society for Testing and Materials (ASTM) to construct 28-day compressive strength of $40 \mathrm{MPa}$ and to give a slump of 12$38 \mathrm{~mm}$. For concrete mix, the water volume ( $\mathrm{pH}$ value $\sim 7$ at zero turbidity) used for the preparation of the control sample was $200 \mathrm{~L} / \mathrm{m}^{3}$ while in the case of the bio-concrete sample, $200 \mathrm{ml} / \mathrm{L}$ from total water volume was replaced with Bact-Cal solution which composed of bacterial spore suspension $\left(1 \times 10^{5} \mathrm{CFU} / \mathrm{ml}\right)$ and calcium lactate $(252 \mathrm{~g} / \mathrm{L})$, the mix proportions are listed in Table 1 . Control and bio-concrete specimens were cast in the form of cubes and cylinders with different dimensions Figure (1) and Table (2). All control and bio-concrete specimens were cured for 28 days separately in water tanks.

\subsection{Evaluation of bacterial consortium effect on the properties of concrete.}

To evaluate the effect of bacteria on the properties of concrete, the prepared samples of both control and bio-concrete were subjected to different tests as follows:

\subsubsection{Compressive Strength Test}

Compressive strength is a very important feature in concrete properties. It means the ability of concrete to bear loads. The specimens were taken out of the water and tested as soon as they were still wet. It was subjected to compressive strength testing using a compression testing machine as in Figure (2-A\}, according to (ASTM C39, 2017). The load was applied and increased continuously by about $13.5 \mathrm{KN} / \mathrm{sec}$ till the resistance of the specimen to the increased load collapses until no larger load can be handled. The final load was noted, and the compressive 
strength of the specimen was calculated by dividing the maximum load by the cross-sectional area of the specimen. The compressive strength experiment was performed on three specimens of control and bio-concrete at curing ages 7 and 28 days and the average values were taken.

\subsubsection{Splitting Tensile Strength Test}

The concrete splitting tensile strength is checked on a cylinder employing a density testing machine, the procedure was started on the (ASTM C496, 2017). Initially, the specimen was placed between the load sides of the testing machine horizontally as represented in Figure (2-B), the continuous load was used without shock at a rate in the range of 0.7 to $1.4 \mathrm{MPa} / \mathrm{min}$ until the cylinder failure. This used load induces stretchable pressures on the plane which contain the applied load, producing tensile failure of the specimen. The splitting tensile strength will be measured by dividing the maximal used load by the suitable geometrical factors. A splitting tensile strength test was performed on three specimens of control and bio-concrete at different curing ages: 7 and 28 days.

\subsubsection{Durability Properties (Permeability Test).}

The German Water Permeation Test (GWT) was used to calculate the quantity of water that enters the substrate in the presence of conditions with controlled pressure as in Figure (2-C), the cubes of control and bio-concrete specimens were subjected to a constant water pressure of $100 \mathrm{KPa}$ on curing periods of 7 and 28 days. Then, the gauge readings were documented on time in millimeters and utilized to calculate the water penetration characteristics of the surface tested. Usually, a single test takes about 5-10 minutes, according to the quality of concrete (Andrzej and Marta, 2016).

\subsubsection{Non-Destructive Testing (Ultrasonic Pulse Velocity (UPV) Test)}

The UPV test was done as had been performed by (ASTM C 597, 2016) UPV testing of concrete is constructed on the pulse velocity procedure mainly to give data on the consistency of concrete, occurrence of holes, cracks, and deficiencies. The pulse speed varies according to its compactness and elastic features. Direct transmission measurements on cylinders were implemented using the portable digital indicator tester known as PUNDIT. This test was conducted by passing a pulse through concrete specimens, then UPV was measured for three specimens of control and bioconcrete cylinders which cured in water for 7 and 28 days. The average velocity was recorded. Higher velocities indicate a good internal healing rate of cracks, while slower velocities indicate poor crack healing. 


\subsubsection{Visual and SEM microscopy evaluation}

Cracks were generated in the specimens by loading specimens with axial load approximately $10 \%$ of the target load after one day of curing of both control and bio-concrete specimens in water separately. After curing for 28 days, the cracked specimens underwent a visual inspection and photographed at different time intervals $(1,7,14$, and 28 days $)$ to observe the surface healing. For scanning electron microscope (SEM), after 28-day of curing some broken pieces of concrete near cracked surfaces in both control and bio-concrete were collected to be visualized by SEM. Samples were dried for $24 \mathrm{~h}$. at $60^{\circ}$ (Basha et al., 2018). The sample surface was micrographed using Quanta FEG 250 scanning electron microscope (FEI Company, USA) presented at Desert Research Center (DRC), Cairo. Samples were installed on the stubs of SEM. The conditions of applied SEM were a $10.1 \mathrm{~mm}$ working distance, with an in-lens sensor and an excitement voltage of $20 \mathrm{kV}$.

\subsubsection{X-ray Diffraction (XRD)}

The XRD analysis was done using precipitates formed at the surface of the crack after 28 days of curing to determine the crystal structure of the investigated specimens. For this purpose, the precipitates formed inside the cracks were scratched and examined by X-ray Diffractometer at a spectrum ranging from 2 Theta $=0^{\circ}$ to $90^{\circ}$. This analysis was done using Shimadzu apparatus with nickel filter and $\mathrm{Cu}-\mathrm{Ka}$ target, Shimadzu Scientific Instruments (SSI), Kyoto, Japan, at National Center for Radiation Research and Technology (NCRRT), Cairo, Egypt.

\section{Statistical analysis}

The data were examined by analysis of variance (ANOVA), and the average comparison was done by Tukey's test and 95\% Confidence. All the analyses were performed by using Minitab 18.1. and graphed by Microsoft office 365.

\section{Result and discussion}

\section{Isolation of endospore-forming bacteria.}

In the current study, potential isolates with the required characteristics were searched in samples originating from the locality with extreme conditions such as alkaline, hot, and saline habitats. According to the variation in morphological characteristics of bacterial colonies, only six bacterial isolates were picked up after cultivation of a pretreated sediment sample on NA medium. These isolates were coded as MK, NW-1, NW-3, NW-5, NW-7, and NW-9. The micrographs captured under the light microscope (Olympus (2000 x) appeared the tested bacteria as blue, violet, or purple bacterial cells, indicating that all isolates were Gram-positive bacteria Figure (3-A). Also, the 
endospores designated by green rods within red or pink cells were visible in the results obtained from endospore staining for all investigated cultures Figure (3-B). This means the bacterial isolates can form endospores. Endospores are a special resistant dormant stage of bacteria with strong cell walls that is capable of surviving in harsh conditions for a long time (Sagripanti and Bonifacino, 1996). The development of endospores makes the bacteria able to resist extreme environmental, mechanical, and chemical stresses through the mixing of concrete (Jonkers and Schlangen, 2007). In good environments, endospores can grow and converted to vegetative bacterial cells in 90 minutes. These vegetative cells can repair and fill the cracks with $\mathrm{CaCO}_{3}$ in case of entry of water and air into concrete (Krishnapriya et al., 2015).

\section{Tolerance of bacterial isolates to alkaline $\mathrm{pH}$ and high temperature}

The results represented graphically in Figure (4-A) revealed that NW-3, NW-5, and NW-7 isolates were considered neutrophilic bacteria that were not able to survive well in alkaline conditions. The NW-1 isolate was tolerated alkalinity with moderate growth at $\mathrm{pH} 10$ and weak growth at $\mathrm{pH} 11$ then it could not grow at $\mathrm{pH}$ 12. Among all isolates, MK and NW-9 were able to grow at $\mathrm{pH} 12$ exhibiting maximum growth at pH 10 as compared to other isolates. So, MK and NW-9 may characterize as alkaliphilic isolates. The microbes that able to grow perfectly at $\mathrm{pH}$ values above $\mathrm{pH}$ 9, often in the 10-13 range of $\mathrm{pH}$ called alkaliphiles (Preiss et al., 2015). Alkaliphilic bacteria like Bacillus species can live in concrete with its extreme conditions; consequently, they are the highly targeted genus of bacteria for bio self-sealing concrete (Seifan et al., 2016). To use the bacteria in the biological treatment of concrete, the bacterial isolates should have the ability to live at very variable degrees of temperature, particularly elevated temperatures. The results refer to our bacterial isolates were grown well at $20^{\circ} \mathrm{C}$ and displayed maximum growth at $40{ }^{\circ} \mathrm{C}$ but at $60{ }^{\circ} \mathrm{C}$, only MK, NW-1, and NW-9 isolates were showed an ability to grow at $60{ }^{\circ} \mathrm{C}$ moderately Figure (4-B). The $\mathrm{pH}$ of fresh concrete is usually between 10 to 13 and its temperature can go up to $70{ }^{\circ} \mathrm{C}$ (Talaiekhozan et al., 2014). Therefore, the selected bacteria need to exhibit high resistance against high $\mathrm{pH}$ and temperature. According to the previous screening which includes Gram staining, spore staining, and tolerance to high alkalinity and high temperature, the isolates named MK, NW1 and NW-9 were only selected for the next studies.

\section{Qualitative urease assay}

Qualitative determination of urease production was performed by observation the color change of the $\mathrm{pH}$ indicator (phenol red) amended in the media from yellow to red after incubation for $48 \mathrm{~h}$. 
312 This occurs according to the quantity of ammonia produced from the hydrolysis of urea by the

313 bacterial urease. In this test, the three Gram-positive spore-forming alkaliphilic thermotolerant

314 isolates were exhibited positive urease activity Figure (4-C). The bacterial isolates involved in bio

315 concrete preferably can break down urea. The urease enzyme breaks down urea, producing both

316 ammonia and carbonate. The produced ammonia increases the $\mathrm{pH}$ of the environment. This

317 situation increases the binding of carbonate with calcium ions found in the environment causing

318 the development of $\mathrm{CaCO}_{3}$ precipitates (Lee and Park 2018; Chaparro-Acuña et al., 2018; Syarif

319 et al., 2019).

320 4. Antagonistic activity of the tested isolates

321 The results revealed that there is no bacterial isolate that inhibited the growth of the other two

322 bacterial, meaning that, these bacterial isolates can be used for the preparation of synthetic bacterial

323 co-culture (bacterial consortium). Artificial microbial consortia mean a simple microbial

324 population designed with a well-defined makeup of two or above (normally 2-3) species/strains

325 (Che and Men, Y2019). Artificial consortia of microbes have been offered for various functions

326 in ecological biotechnology, biomedicine, and industry (Mauri et al., 2020).

\section{5. Calcium carbonate precipitation in broth culture and acid fizz observation}

328 In this experiment, we have tested three potential isolates as a pure and mixed culture for acid fizz formation and calcium carbonate precipitation in comparison with the control medium. To make sure the produced precipitate is calcium carbonate; an acid fizz reaction was performed. calcium carbonate produces gas bubbles when reacting with hydrochloric acid (10\%) because of carbon dioxide release (Abudoleh et al., 2019). This reaction was given positive results with all tested cases confirming the formation of calcium carbonate by these bacterial cultures while the control medium (without bacteria) did not show any effervescence after the addition of 2 drops of $10 \%$

$335 \mathrm{HCl}$ indicating the absence of calcium carbonate in the control sample. Referring to the results of calcium carbonate precipitation, Figure (4-D )emphasized the formation of calcium carbonate in all cases whether in form of pure or mixed culture. Significantly, NW-1 has produced the lowest weight of calcium carbonate. There was not a significant difference between the weight of calcium carbonate formed by NW-9, MK isolates as a pure culture. In all cases of bacterial consortia including NW-1+ NW-9, NW-1+MK, and NW-1+NW-9 +MK, calcium carbonate precipitation significantly more increased than all treatments of pure bacterial cultures. Surprisingly, the mixed 
cases. The selection of the most suitable bacteria for self-healing concrete is mostly based on their calcium carbonate yield. So, MK and NW-9 isolates were characterized and used as mixed cultures (artificial small bacterial consortium) in the next studies. The creation of artificial microbial consortia has created a new way in synthetic biology, focusing on the system's complexity and functionality. Hence, the consortia generate a different condition for microbial species, causing stimulation of silent gene expression, which does not happen in "normal" culturing conditions (Qian et al., 2020).

\section{Molecular characterization of potential bacterial isolates}

Analysis of $16 \mathrm{~S}$ rDNA partial sequences (804 and $1152 \mathrm{bp}$ ) of MK and NW-9 isolates revealed its homology (99\%) with Bacillus flexus strains IFO15715 and Bacillus haynesii strain NRRL B41327 which found in GenBank databases respectively Figure (5). So, MK and NW-9 isolates were designated as Bacillus flexus MK-FYT-3 and Bacillus haynesii MK-NW-9. The 16S rDNA sequences of Bacillus flexus MK-FYT-3 and Bacillus haynesii MK-NW-9 were deposited to GenBank under accession numbers MN965692 and MN965693respectively. Bacteria belonging to the genus Bacillus are used as strong and reliable self-healing agents. Several studies reported that most of the calcite-forming capacity was mainly detected in species belonged to the genus Bacillus and then used to increase the durability of concrete ( Zhang et al., 2016; Abdulkareem et al., 2019; Vashisht and Shukla, 2020).

\section{Evaluation of bacterial consortium effect on the properties of concrete}

The principle of the crack bio sealing depends on that the bacterial species should have the capacity of soluble organic nutrients transformation into insoluble inorganic $\mathrm{CaCO}_{3}$ precipitates that fill the cracks. So, bacterial consortiums which consisted of Bacillus flexus MK-FYT-3 and Bacillus haynesii MK-NW-9 at an equal ratio in addition to calcium lactate as a nutrient for bacteria were incorporated immediately when mixing of concrete begins.

\subsection{Compressive Strength}

The data represented in Figure (6-a) explain that the increase of compressive strength in both types of concrete is time-dependent which means, it was significantly increased with time increasing. In general comparison with control, the compressive strength of the bio-concrete specimen was significantly more than control at 7 and 28 days of curing. It was increased by 31.29 and $36.3 \%$ at the age of 7 and 28 days, respectively. The improvement in compressive strength by bacterial consortium may be due to the bio-deposition of calcium carbonate around the cell and inside the 
374 holes of the concrete structure. Similarly, the results of compressive strength in agreement with

375 the results of the research carried out by (Nguyen et al., 2020) who noted that Bacillus subtilis could lead the compressive strength to $40 \%$ higher than the controls when used as a crack healing agent in the concrete samples.

\subsection{Splitting Tensile Strength}

By studying the split tensile strength of concrete, it was found that there are significant differences between bio-concrete and control specimens at 7 and 28 days as shown in Figure (6-b), the results show an increase in splitting tensile strength of bio-concrete specimens by $29 \%$ and $39 \%$ respectively at curing ages 7 and 28 days more than the control. Regardless of age, there is no significant difference between the control specimens after 28 days and the bio-concrete specimens after only 7 days of curing. Rao et al., (2015) noted a significant result as compared to normal concrete. It showed an increase of over $10 \%$ in the split tensile strength after their curing for 28 days. On the other hand, Shashank et al., (2018) when added Bacillus sphaericus with a concentration of $10^{7}$ cells $/ \mathrm{ml}$ in the concrete, detected a $29 \%$ rising in the split-tensile strength of concrete than control. This occurred by the action of the bacteria that formed calcium carbonate in the concrete matrix, which lead to rising in the load resisting strength of the concrete. The variation between our result and the other may be attributed to the bacterial types and concentrations used, the overall enhanced tensile strength in bio-concrete is beneficial as it indicates that the probability of cracks formation is few to happen, and therefore concrete will sustain for a long time.

\subsection{Permeability}

The water permeability of concrete depends on the porosity and connection of the pores together.

Therefore, the higher the porosity of concrete, the more likely it is to deteriorate. Low permeability is essential to prevent destructive compounds from entering the concrete, allowing it to endure longer (Molyneux, 2021). As illustrated in Figure (6-c), the results of the water permeability test showed a significant reduction in bio-concrete specimens by 21.1 and $23.1 \%$ compared with control specimens after curing for 7 and 28 days respectively. We also detected that the permeability of both control and bio-concrete specimens after 7 days of curing was significantly higher than that observed after 28 days. Commonly, less permeable concrete means that concrete has less water absorption capacity. The accumulation of a layer of calcium carbonate precipitates on the surface caused a reduction in the water permeability. A reduction in water absorption leads to a slowing down of the effect of climate change. So, a repairing coating of calcium carbonate 
can behave as a natural calcite skin on the surface of bio-concrete (Achal et al., 2013). The observed reduction of water permeability in bio-concrete specimens reflects the action of the bacterial consortium representing a solution to one of the main problems concerning concrete durability (Alshalif et al., 2019). our results in agreement with several reports (Luo et al., 2015; Tziviloglou et al., 2016; Balam et al 2017; Choi Sun-Gyu et al., 2017; Shashank and Nagaraja, 2021).

\subsection{Ultrasonic Pulse Velocity (UPV)}

An ultrasonic pulse is delivered across the tested concrete and its travel time is determined. When concrete is characterized with decent quality from the view of compactness, uniformity, and homogeneity, greater velocity has to be gained. The data represented in Figure (6-d) referred to the pulse velocity of bio-concrete specimens was significantly increased by $26 \%$ and $20 \%$ than control specimens after their curing for 7 and 28 days respectively. It is also clear that pulse velocity was increased significantly with increasing curing time in both control and bio-concrete. Bio-concrete specimens showed a compact and dense structure due to calcium precipitation which reduced the internal cracks volume which was confirmed by the ultrasonic pulse velocity test results. In this investigation, it was discovered that adding bacteria to concrete improves its mechanical qualities whereas the development of calcite in the nanopore of concrete causes reduction of water permeation and the increase in compactness and then their strength.

\subsection{Visual Observation of self-healing}

Figure (7) shows diverse widths of cracks in specimens of control and bio-concrete after different healing stages. Bio-healing was observed in the specimens containing bacterial consortium in the shape of white crystals or powder through curing intervals. The time required for the complete healing of cracks with various widths was different. The crack with a width of $0.1 \mathrm{~mm}$ was partially repaired through 7 days and filled after 28 days of curing with tap water. The crack with a width of $2 \mathrm{~mm}$ was nearly fully healed after 28 days of curing in water in addition to the filling of some holes which naturally present in bio-concrete specimens. For control specimens, cracks with different widths of 0.10 and $2 \mathrm{~mm}$ did not close even after 28 days. There is some surface precipitation with no effect after 28 days of curing. According to Nguye et al., (2020) (0.10 mm or smaller cracks in specimens of control can be appeared smooth and closed by late hydration and the reaction of $\mathrm{Ca}(\mathrm{OH})_{2}$ with $\mathrm{CO}_{2}$ in the natural self-healing process. 
The SEM analysis of bio-concrete specimens inoculated with bacterial consortium generally revealed that different crystalline structures cannot be seen in the control specimen (controlconcrete). In Figure (8), at 400X, there are deposits in the bio-concrete sample resembling a rough sponge which was not seen in the control specimen at the same magnification power. At 3000X, an SEM scan of the bio-concrete sample shows a sealed crack with biopolymers-like material, which could be the consequence of bacterial cells attaching to one other on a surface to form a network, as well as little calcium carbonate crystals that appear as needles or spheres. At 5000X, SEM images showed the growth and distribution of precipitated $\mathrm{CaCO}_{3}$ that was not uniformly distributed on the crack surfaces. These precipitates appeared as irregular shapes crystals and cluster-like precipitates composed of small spherical crystals. At 6000X, Multiple shapes also appeared, but the predominant crystals are cubic, in addition to both the rod and irregularly shaped crystals. All these notes were not observed in the control specimen at the same scales. These results agree with the previous studies which also reported the difference between the surfaces of bioconcrete and control samples. The surfaces of untreated concrete seemed to be amorphous, without obvious $\mathrm{CaCO}_{3}$ crystals appearance. In contrast, bio-concrete samples demonstrated crystalline surfaces where distinct $\mathrm{CaCO}_{3}$ crystals may recognize (Krishnapriya et al, 2015; Siddique et al, 2016; Alshalif et al, 2019). Reda et al., (2020) were reported that Bacillus flexus is the most potent one amongst the bacterial isolates that can form biofilm. Also, Rajitha et al, (2020) was noted that Bacillus haynesii produce acid-soluble extracellular biopolymer. The ability of both bacterial isolates to form biopolymer may be the cause of the network appearing on the crack surface of the bio-concrete sample

\subsection{X-ray Diffraction (XRD)}

Figure (9) shows X-ray diffraction (XRD) analysis of control-concrete and bio-concrete. The sample constituents were recognized through their comparison with standards of the International Centre for Diffraction Data. Even though the main typical calcite peaks in bio-concrete and control samples emerged at $2=29.38^{\circ}$ and $29.51^{\circ}$, respectively, which match to crystal planes (104), but the peak intensity appears to be higher in the bio-concrete than in the control specimen. This implies an increase in the concentration of precipitated calcium carbonate with increasing peak heights in the bio-concrete sample. The XRD pattern indicates the presence of three polymorphic calcium carbonate crystals (calcite, vaterite, and aragonite) in both the bio-concrete and the control specimen. However, calcite is predominant in the bio-concrete specimen, unlike vaterite that is 
dominant in the control specimen. XRD is a fast-investigating approach for identifying diverse compounds derived from microbes. Calcite and vaterite have previously been identified as major crystal forms in bacterial concrete (Merve et al, 2019). The data strongly suggested that bacterial consortium which consisted of Bacillus flexus MK-FYT-3 and Bacillus haynesii MK-NW-9 can promote calcium carbonate precipitation. These findings agree with the results reported in several studies (Kalhori and Bagherpour, 2017; Seifan et al, 2016; Chen et al, 2016; Chaerun et al, 2020).

\section{Conclusion}

The bacterial consortium composed of Bacillus flexus MK-FYT-3 and Bacillus haynesii MK-NW9 has not the ability to seal cracks only but also improve the properties of bacterial concrete. The compressive and tensile strengths of bacterial concrete are significantly increased than control samples, and the high density of their material makes it more durable. The permeability is decreased, lowering the entry of damaging materials which could harm the structure of the concrete. This research will give a technologically enhanced, environmentally friendly, pollutionfree, and non-hazardous approach for achieving the most environmentally clean self-healing of concrete.

\section{Authors Contributions}

H.H. A. M.: Preparation of concrete samples and measuring their mechanical properties. M. H. A. K.: Collection of sediment samples, isolation, screening, and identification of $\mathrm{CaCO}_{3}$ producing bacterial strains; co-wrote the manuscript. G. M. E. S.: Participation in the development of the research plan, interpretation of the results of the microbiological aspects, and revision of the manuscript. A. E. A. M.: Conceiving the presented idea and supervision of the research; co-wrote the paper. M. E. A. O.: Contribution to the interpretation of the findings of concrete mechanical property testing and manuscript review. W. M. F. T.: Characterization of all concrete samples and investigation of its microstructure; co-wrote the manuscript. The manuscript was reviewed and approved by all authors prior to submission for peer review. All authors read and approved the final manuscript.

\section{Acknowledgments}

Not applicable.

\section{Availability of data and materials}

All data generated or analyzed during this study are included in this published paper.

\section{Funding}

N/A 


\section{Declarations}

Ethics approval and consent to participate

Not applicable.

\section{Consent for publication}

Not applicable.

\section{Competing interests}

The authors declare that they have no competing interests.

\section{References}

Abdulkareem, M., Ayeronfe, F., Abd Majid, M. Z., Sam, A. R. M., Kim, J. H. J. (2019). Evaluation of effects of multi-varied atmospheric curing conditions on compressive strength of bacterial (Bacillus subtilis) cement mortar. Construction and Building Materials, 218, 1-7.

Abudoleh, S. M., Al Mahayreh, A., Al Frejat, A., Al Hulaisy, F., Hamdan, S. O. (2019). Bio concrete Development Using Calcite-Precipitating Bacteria Isolated From Different Sources in Jordan. In MATEC Web of Conferences 278. 01011. EDP Sciences.

Achal, V., Mukerjee, A., Reddy, M. S. (2013). Biogenic treatment improves durability and remediates the cracks of concrete structures. Construction and Building Materials, 48, 1-5.

Alshalif, A. F., M. I. Juki, N. Othman, A. A. Al-Gheethi, F. S. Khalid (2019). "Improvement of mechanical properties of bio-concrete using Enterococcus faecalis and Bacillus cereus." Environmental Engineering Research 24(4): 630-637.

Al-Tabbaa, A., Lark, B., Paine, K., Jefferson, T., Litina, C., Gardner, D., Embley, T. (2018). Biomimetic cementitious construction materials for next-generation infrastructure. Proceedings of the Institution of Civil Engineers-Smart Infrastructure and Construction, 171(2), 67-76.

Altschul, S. F., Gish, W., Miller, W., Myers, E. W., Lipman, D. J. (1990). Basic local alignment search tool. Journal of molecular biology, 215(3), 403-410.

Andrzej, M. and M. Marta (2016). "GWT-New Testing System for "in-situ" Measurements of Concrete Water Permeability." Procedia Engineering 153: 483-489.

ASTM C39 / C39M-17a, Standard Test Method for Compressive Strength of Cylindrical 
Concrete Specimens, ASTM International, West Conshohocken, PA, 2017, www.astm.org. ASTM C496 / C496M-17, Standard Test Method for Splitting Tensile Strength of Cylindrical Concrete Specimens, ASTM International, West Conshohocken, PA, 2017, www.astm.org. ASTM C597-16, Standard Test Method for Pulse Velocity Through Concrete, ASTM International, West Conshohocken, PA, 2016, www.astm.org.

Balam, N. H., Mostofinejad, D., Eftekhar, M. (2017). Effects of bacterial remediation on compressive strength, water absorption, and chloride permeability of lightweight aggregate Construction and Building Materials, 145, 107-116.

Basha, S., Lingamgunta, L. K., Kannali, J., Gajula, S. K., Bandikari, R., Dasari, S., Balaji, V. K. (2018). Subsurface endospore-forming bacteria possess bio-sealant properties. Scientific reports, 8(1), 1-13.

Chaerun, S. K., Syarif, R., Wattimena, R. K. (2020). Bacteria incorporated with calcium lactate pentahydrate to improve the mortar properties and self-healing occurrence. Scientific reports, 10(1), 1-9.

Chahal, N., Rajor, A., Siddique, R. (2011). Calcium carbonate precipitation by different bacterial strains. African Journal of Biotechnology, 10(42), 8359-8372.

Chaparro-Acuña, S. P., Becerra-Jiménez, M. L., Martínez-Zambrano, J. J., RojasSarmiento, H. A. (2018). Soil bacteria that precipitate calcium carbonate: mechanism and applications of the process. Acta Agronómica, 67(2), 277-288.

Chen, H., Qian, C., Huang, H. (2016). Self-healing cementitious materials based on bacteria and nutrients immobilized respectively. Construction and Building Materials, $126,297-303$.

Che, S., Men, Y. (2019). Synthetic microbial consortia for biosynthesis and biodegradation: promises and challenges. Journal of Industrial Microbiology and Biotechnology, 46(9-10), 1343-1358.

Choi Sun-Gyu, Wang Kejin, Wen Zhiyou, Chu Jian. (2017). Mortar crack repair using microbial-induced calcite precipitation method. Cement and Concrete Composites.83, 209-221.

Code, E. (2007). "Egyptian Code of Practice for Concrete Structures, HBRC." Arabic, Cairo, Egypt.

De Belie, N., Gruyaert, E., Al-Tabbaa, A., Antonaci, P., Baera, C., Bajare, D., Litina, C. 
(2018). A review of self-healing concrete for damage management of structures.

Advanced materials interfaces, 5(17), 1800074.

Dhami, N.K., Mukherjee, A., Reddy, M.S., 2016. Micrographical, mineralogical, and nanomechanical characterization of microbial carbonates from urease and carbonic anhydrase-producing bacteria. Ecol. Eng. 94, 443-454.

EN, B. (2009). 12390-8. Testing hardened concrete. Depth of penetration of water under pressure. London: BSI, 1-210.

Ganesh, A. C., Muthukannan, M., Malathy, R., Babu, C. R. (2019). An Experimental Study on Effects of Bacterial Strain Combination in Fibre Concrete and Self-Healing Efficiency. KSCE Journal of Civil Engineering, 23(10), 4368-4377.

Jonkers, H. M., Schlangen, E. (2007,). Crack repair by concrete-immobilized bacteria. In Proceedings of the first international conference on self-healing materials 18,20

Merve, T. E., Arslan, Ş., Koralay, T., DOĞAN, N. M. (2019). Precipitation and characterization of $\mathrm{CaCO} 3$ of Bacillus amyloliquefaciens $\mathrm{U} 17$ strain producing urease and carbonic anhydrase. Turkish Journal of Biology, 43(3), 198.

Kalhori, H., Bagherpour, R. (2017). Application of carbonate precipitating bacteria for improving properties and repairing cracks of shotcrete. Construction and Building Materials, 148, 249-260.

Kim, H. J., Eom, H. J., Park, C., Jung, J., Shin, B., Kim, W., Park, W. (2016). Calcium carbonate precipitation by Bacillus and Sporosarcina strains isolated from concrete and analysis of the bacterial community of concrete. J Microbiol Biotechnol, 26(3), 540-548.

Krishnapriya S, Venkatesh Babu D.L., Prince Arulraj G. (2015). "Isolation and identification of bacteria to improve the strength of concrete." Microbiological research 174: 48-55

Lee, Y. S., Park, W. (2018). Current challenges and future directions for bacterial selfhealing concrete. Applied microbiology and biotechnology, 102(7), 3059-3070.

Luo Mian, Qian Chun-xiang, Li Rui-yang. (2015). Factors affecting crack repairing capacity of bacteria-based self-healing concrete. Construction and Building Materials. 87, 1-7.

Mauri, Marco, Jean-Luc Gouzé, Hidde De Jong, Eugenio Cinquemani. "Enhanced production of heterologous proteins by a synthetic microbial community: Conditions an trade-offs." PLoS computational biology 16, 4 (2020): e1007795.

Messaoudi, O., Bendahou, M., Benamar, I., Abdelwouhid, D. E. (2015). Identification 
and preliminary characterization of non-polyene antibiotics secreted by new strain of actinomycete isolated from sebkha of Kenadsa, Algeria. Asian pacific journal of tropical biomedicine, 5(6), 438-445.

Molyneux, K. (2021). Bacterial Concrete: A Sustainable Building Material with Advantageous Properties. Youth STEM Matters, 1 https://doi.org/10.51892/ysm.1.202101

Moghannem, S. A., Refaat, B. M., El-Sherbiny, G. M., El-Sayed, M. H., Elsehemy, I. A., Kalaba, M. H. (2015). Characterization of heavy metal and antibiotic-resistant bacteria isolated from polluted localities in Egypt. Egyptian Pharmaceutical Journal, 14(3), 158.

Nain, N., Surabhi, R., Yathish, N. V., Krishnamurthy, V., Deepa, T., Tharannum, S. (2019). Enhancement in strength parameters of concrete by application of Bacillus bacteria. Construction and Building Materials, 202, 904-908.

Nguye H., Imamoto K., Kiyohara C. (2020). "Compressive Strength Improvement and Water Permeability of Self-Healing Concrete Using Bacillus Subtilis Natto. XV International Conference on Durability of Building Materials and Components (DBMC)

Qian, X., Chen, L., Sui, Y., Chen, C., Zhang, W., Zhou, J., Ochsenreither, K. (2020). Biotechnological potential and applications of microbial consortia. Biotechnology advances, 40, 107500.

Preiss, L., Hicks, D. B., Suzuki, S., Meier, T., Krulwich, T. A. (2015). Alkaliphilic bacteria with impact on industrial applications, concepts of early life forms, and bioenergetics of ATP synthesis. Frontiers in Bioengineering and Biotechnology, 3, 75.

Pungrasmi, W., Intarasoontron, J., Jongvivatsakul, P., Likitlersuang, S. (2019). Evaluation of microencapsulation techniques for MICP bacterial spores applied in self-healing concrete. Scientific reports, 9(1), 1-10.

Reda, F. M., Hassanein, W. A., Moabed, S., El-Shafiey, S. N. (2020). Potential exploitation of Bacillus flexus biofilm against the cowpea weevil, Callosobruchus maculatus (F.)(Coleoptera: Bruchidae). Egyptian Journal of Biological Pest Control, 30(1), 1-7. Rajitha, K., Nancharaiah, Y. V., Venugopalan, V. P. (2020). Acid soluble extracellular matrix confers structural stability to marine Bacillus haynesii pellicle biofilms. Colloids and Surfaces B: Biointerfaces, 111160.

Rao, R., U. Kumar, S. Vokunnaya, P. Paul, I. Orestis, S. Grade (2015). "Effect of Bacillus Flexus in Healing Concrete Structures." International Journal of Innovative Research in 
Science, Engineering, and Technology 4 (8) 7273- 7280.

Sarkar, M., Adak, D., Tamang, A., Chattopadhyay, B., \& Mandal, S. (2015). Geneticallyenriched microbe-facilitated self-healing concrete-a sustainable material for a new generation of construction technology. RSC advances, 5(127), 105363-105371.

Sagripanti, J. L and Bonifacino, A. (1996). Comparative sporicidal effects of liquid chemical agents. Applied and environmental microbiology, 62(2), 545-551.

Seifan, M., Ebrahiminezhad, A., Ghasemi, Y., Berenjian, A. (2019). Microbial calcium carbonate precipitation with high affinity to fill the concrete pore space: nanobiotechnological approach. Bioprocess and biosystems engineering, 42(1), 37-46.

Seifan, M., Samani, A. K., Berenjian, A. (2016). Bio concrete: next generation of selfhealing concrete. Applied microbiology and biotechnology, 100(6), 2591-2602.

Shashank, B. S., Dhannur, B., Ravishankar, H. N., Nagaraj, P. S. (2018). Study on Strength and Self-healing Behaviour of Bio-Concrete. Civil and Environmental Research, 10, (2):59-67. 2018

Shashank B.S., Nagaraja P.S. (2021) Durability Studies on Low-Strength Bacterial Concrete. In: Biswas S., Metya S., Kumar S., Samui P. (eds) Advances in Sustainable Construction Materials. Lecture Notes in Civil Engineering, 124. https://doi.org/10.1007/978-981-33-4590-4_60

Siddique, R., V. Nanda, E.-H. Kadri, M. I. Khan, M. Singh A. Rajor (2016). "Influence of bacteria on compressive strength and permeation properties of concrete made with cement baghouse filter dust." Construction and Building Materials 106: 461-469.

Silvab, Y. B. B., Sarubbob, L. A., Benachoura, M. (2020). Biomineralization of Calcium Carbonate by Bacillus Cereus for Self-Healing Biocement. Chemical Engineering Transactions 79, 97-102.

Syarif, R., Rizki, I. N., Wattimena, R. K., Chaerun, S. K. (2019). Selection of bacteria inducing calcium carbonate precipitation for self-healing concrete application. Curr Res Biosci. Biotechnol, 1(1), 26-30.

Talaiekhozan, A., Keyvanfar, A., Shafaghat, A., Andalib, R., Majid, M. A., Fulazzaky, M. A., Marwar, N. F. (2014). A review of self-healing concrete research development. Journal of Environmental Treatment Techniques, 2(1), 1-11.

Tan, L., Reeksting, B., Ferrandiz-Mas, V., Heath, A., Gebhard, S., Paine, K. (2020). Effect 
of carbonation on bacteria-based self-healing of cementitious composites. Construction and Building Materials, 257, 119501.

Tziviloglou E, Wiktor V, Jonkers H.M., Schlangen E. (2016). Bacteria-based self-healing concrete to increase liquid tightness of cracks. Construction and Building Materials. 122, $118-125$

Van Mullem, T., Gruyaert, E., Caspeele, R., De Belie, N. (2020). First Large Scale Application with Self-Healing Concrete in Belgium: Analysis of the Laboratory Control Tests. Materials, 13(4), 997

Vashisht, R., Shukla, A. (2020). Potential application of bacteria to improve the selfhealing and strength of concrete. Journal of Building Pathology and Rehabilitation, 5(1), 10.

Vashisht, R., Attri, S., Sharma, D., Shukla, A., Goel, G. (2018). Monitoring biocalcification potential of Lysinibacillus sp. isolated from alluvial soils for improved compressive strength of concrete. Microbiological Research, 207, 226-231.

Xu, H., Lian, J., Gao, M., Fu, D., \& Yan, Y. (2019). Self-Healing Concrete Using Rubber Particles to Immobilize Bacterial Spores. Materials, 12(14), 2313.

Zhang, J. L., Wu, R. S., Li, Y. M., Zhong, J. Y., Deng, X., Liu, B., Xing, F. (2016). Screening of bacteria for self-healing of concrete cracks and optimization of the microbial calcium precipitation process. Applied microbiology and biotechnology, 100(15), 66616670. 
Figures

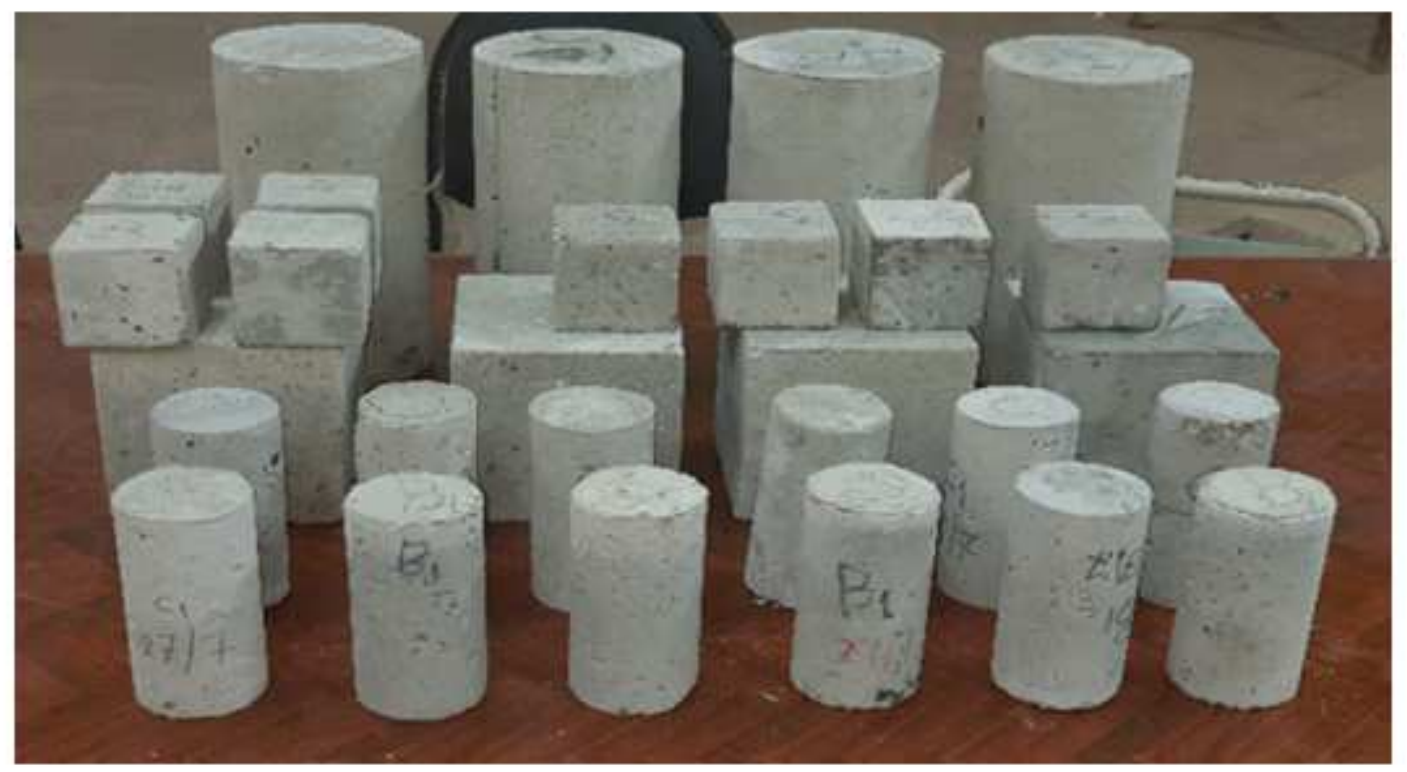

Figure 1

Control and bio-concrete specimens
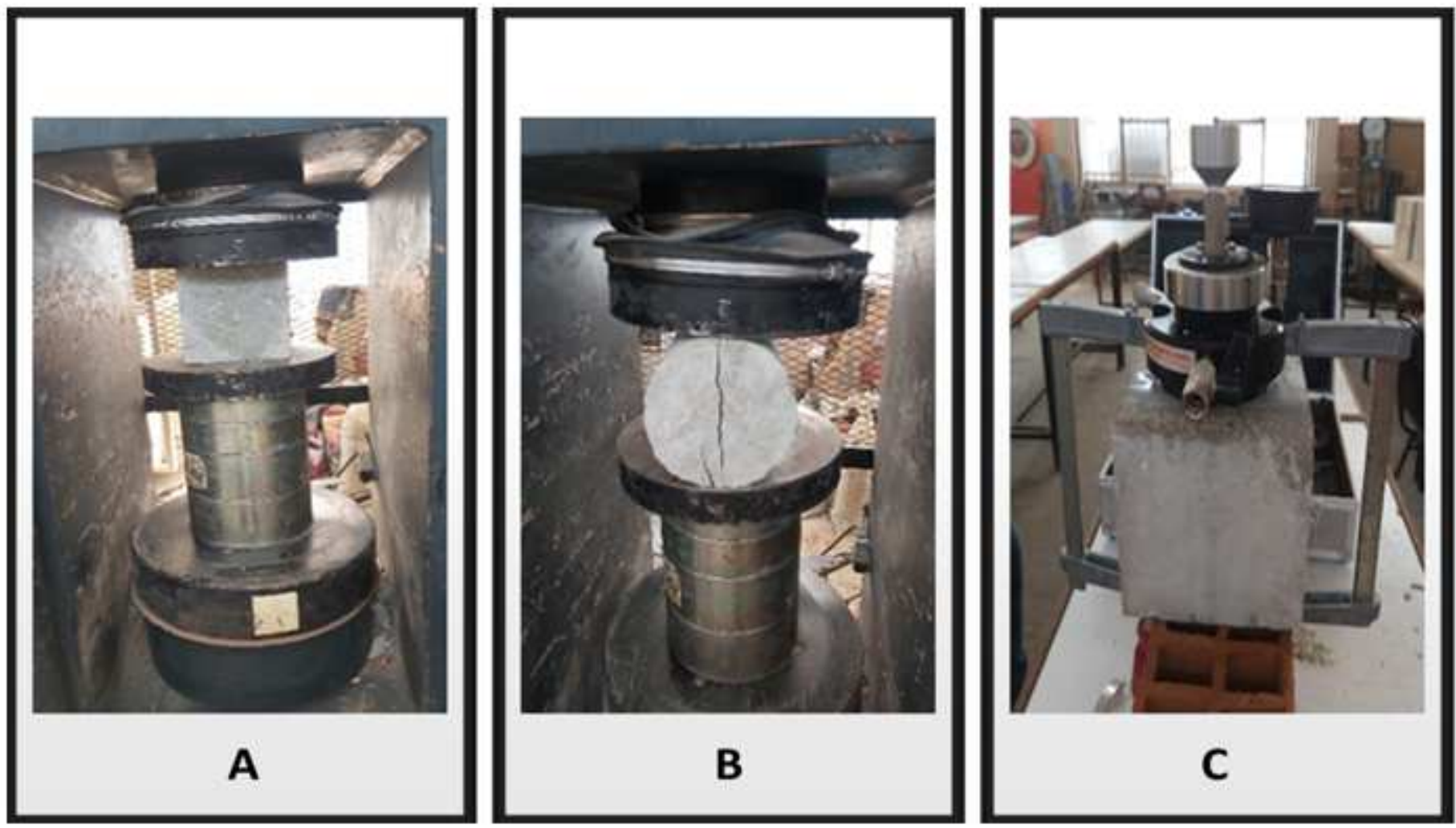

Figure 2 
Compressive strength test machine (A), splitting tensile specimen shape(B), and permeability device with concrete specimen (C).

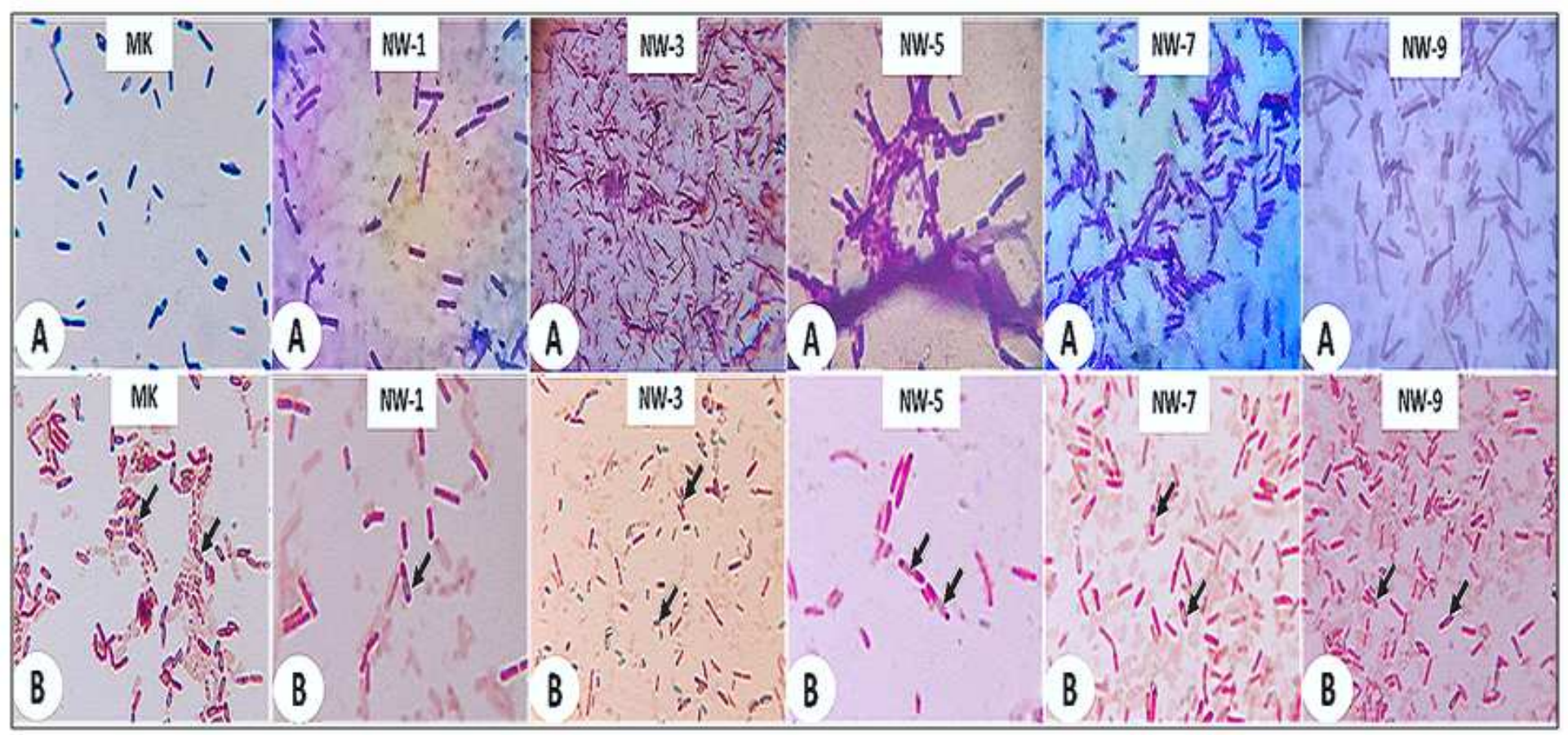

\section{Figure 3}

A; photographs of Gram staining of bacterial isolates. B; photographs of endospore staining of bacteria under the light microscope (2000X). 

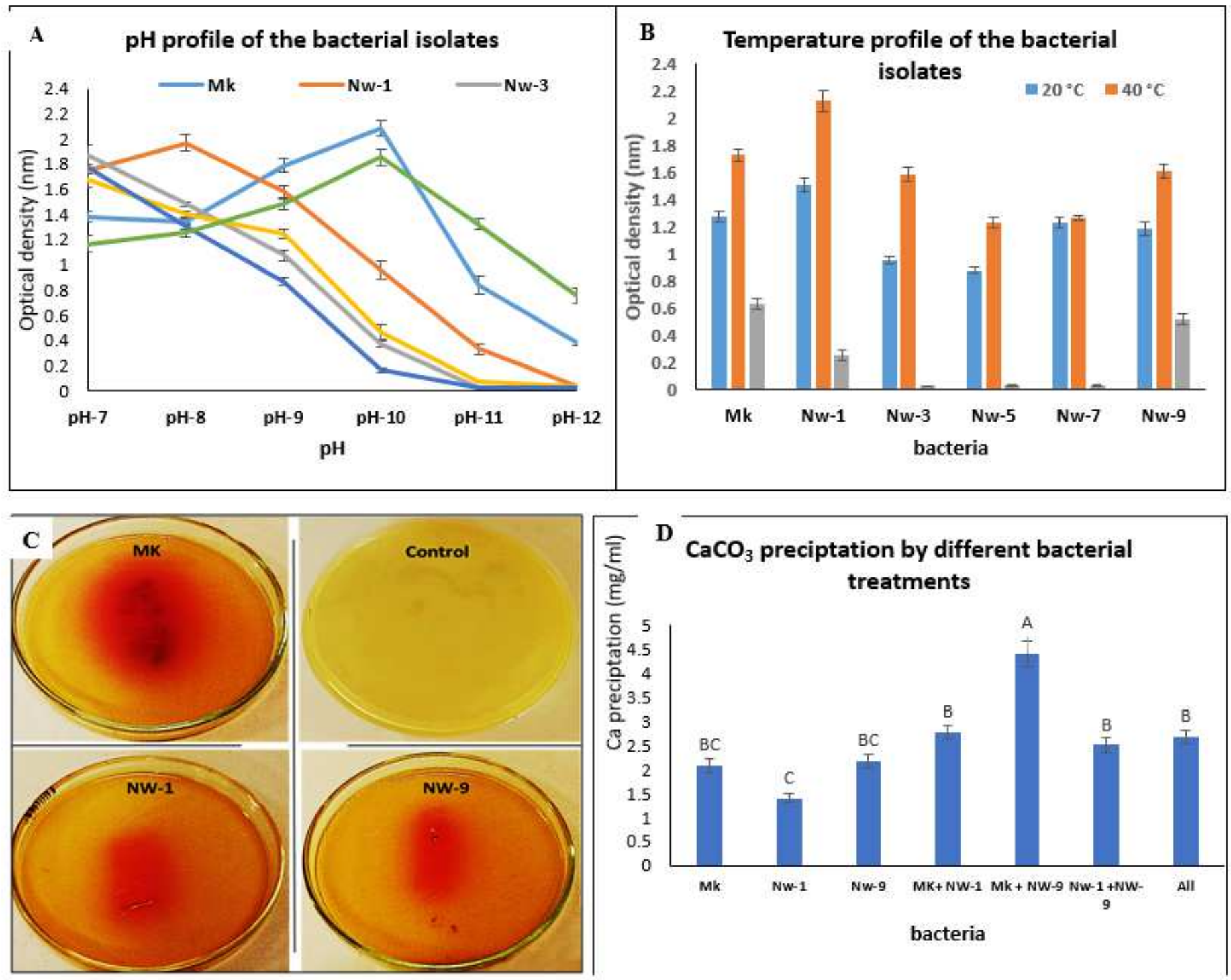

Figure 4

(A) Effects of $\mathrm{pH}$ on the growth of the bacterial isolates (B) growth of the bacterial isolates at different temperatures (C) urease activity of the bacterial isolates after 2 days of incubation (D) weight of $\mathrm{CaCO} 3$ precipitates after 7 days of incubation in NB-U-Ca medium 


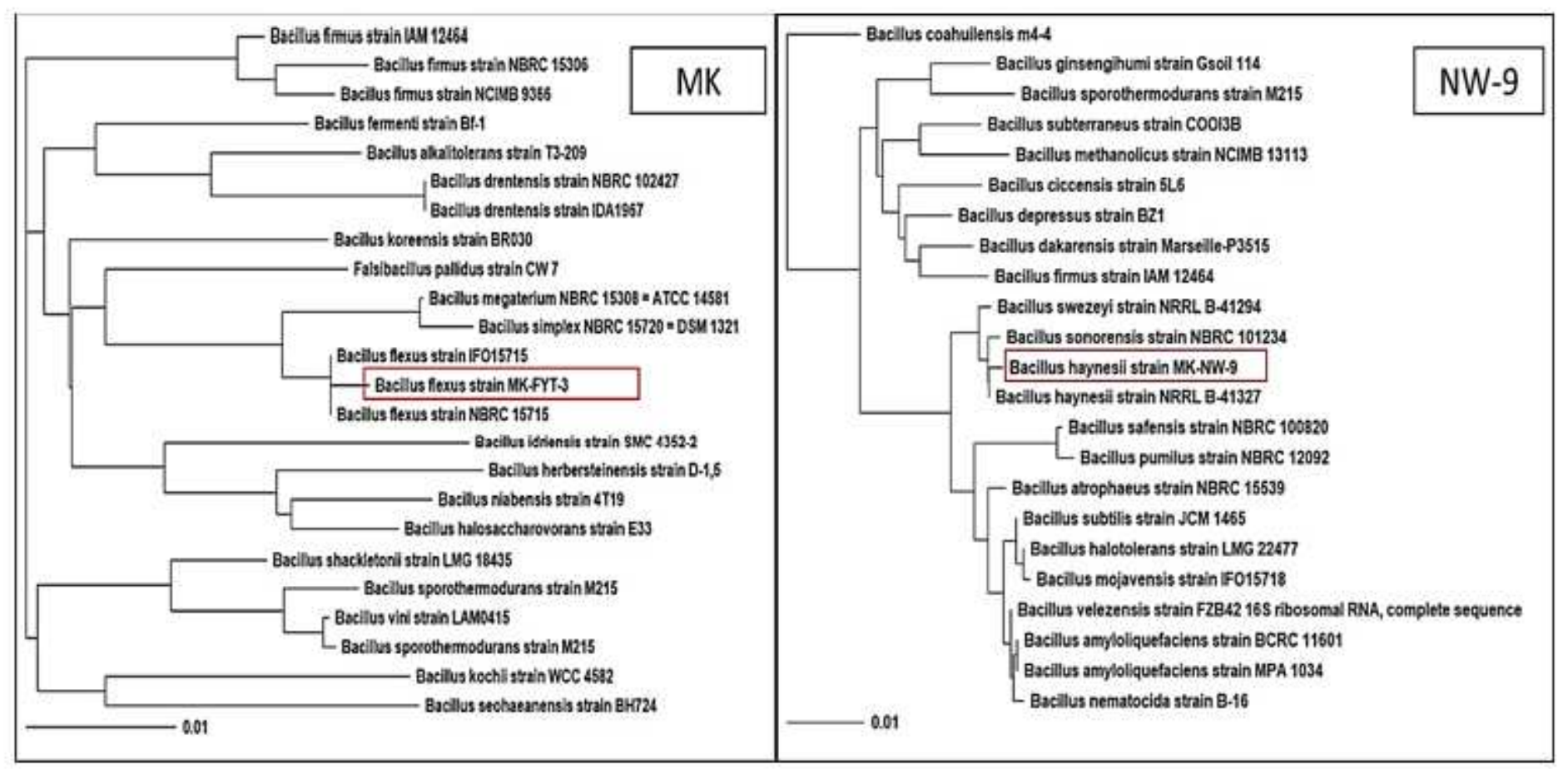

\section{Figure 5}

Phylogenetic trees of Bacillus flexus MK-FYT-3 and Bacillus haynesii MK-NW-9 


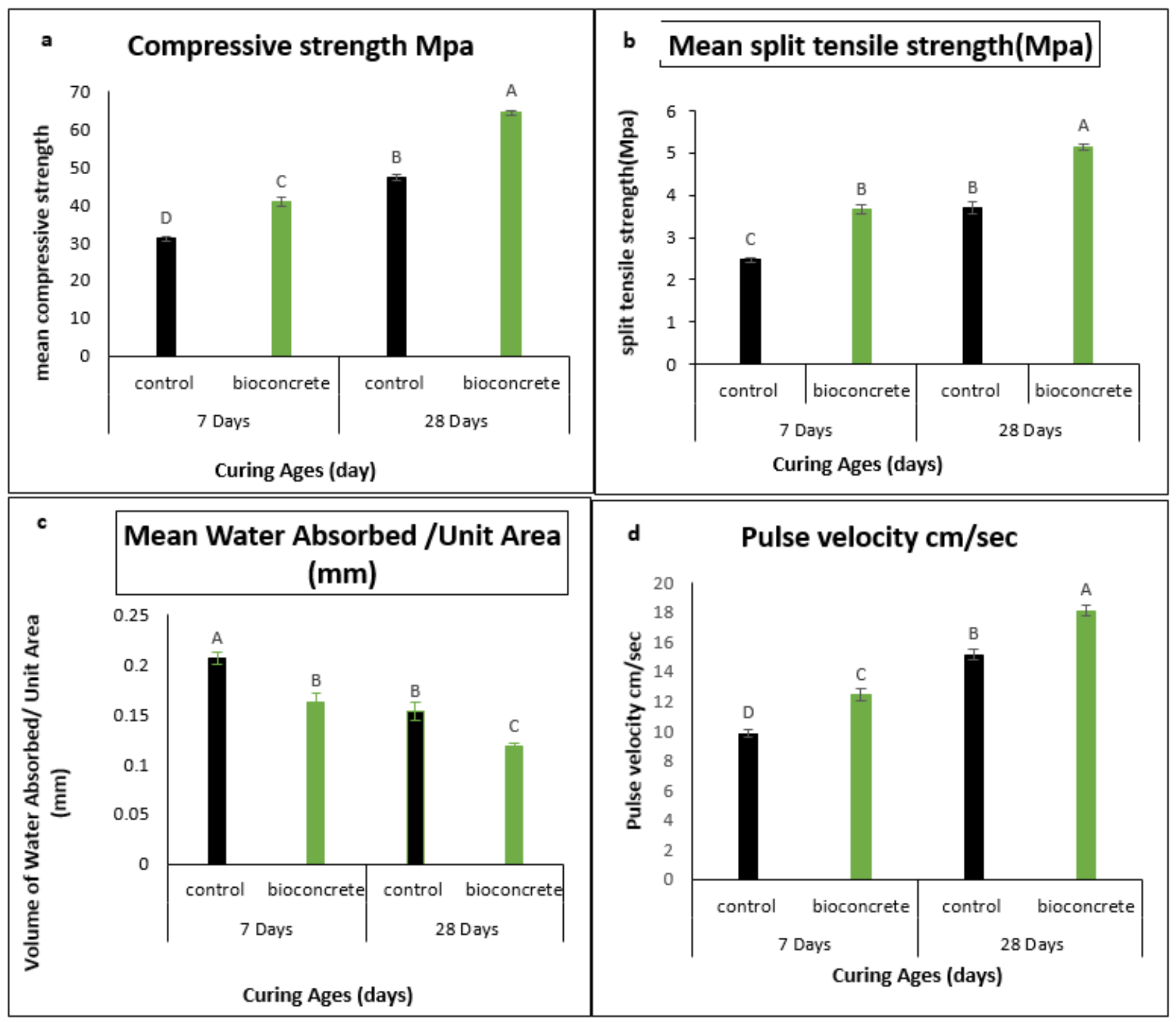

Figure 6

(a) compressive strength of both control and bio-concrete specimens, (b) split tensile strength of concrete and bio-concrete specimens, (c) permeability test of conventional concrete and bioconcrete specimens, (d) ultrasonic pulse velocity test of conventional concrete and bioconcrete specimens. 
Crack width $=0.5 \mathrm{~mm}$

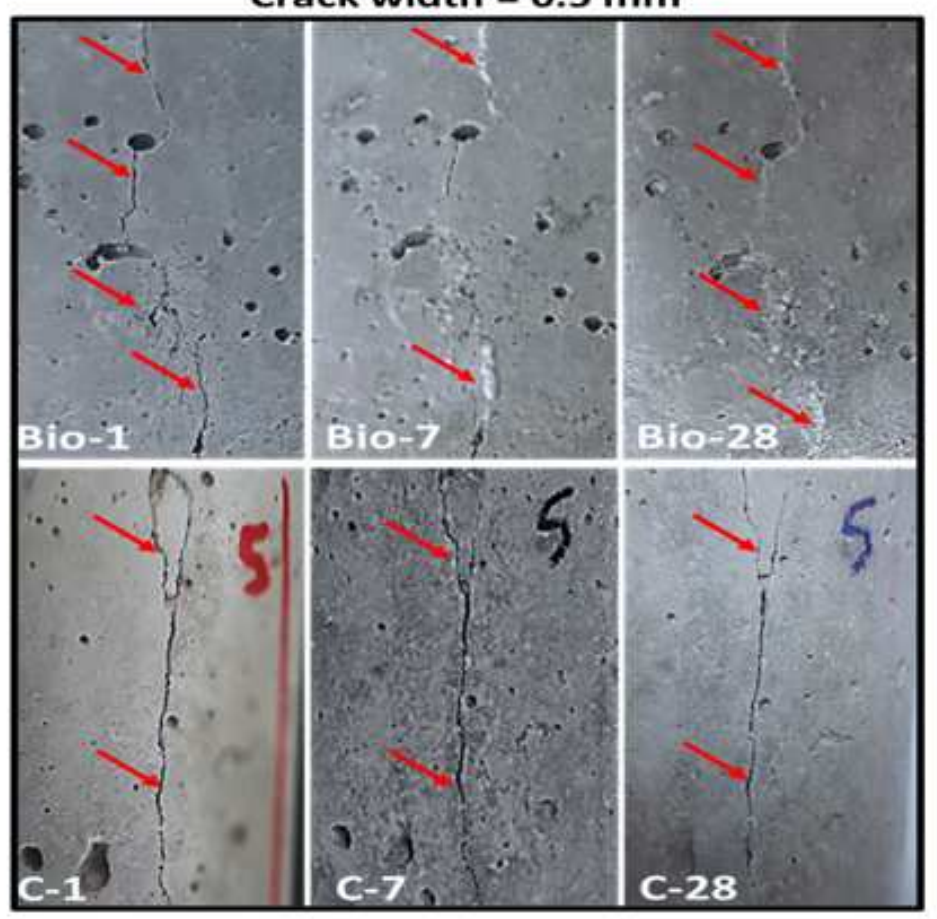

Crack width $=2 \mathrm{~mm}$

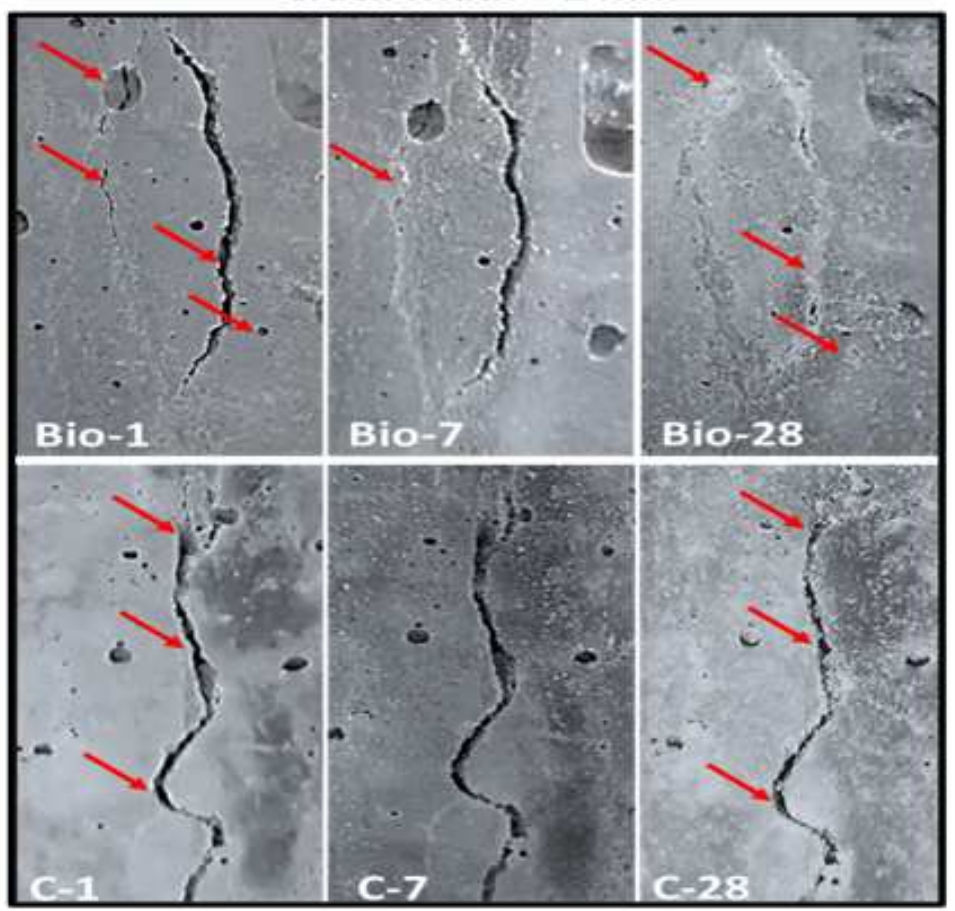

\section{Figure 7}

Visual Observation of self-healing of cracks with 0.5 and $2 \mathrm{~mm}$ in width in both control (C) and bioconcrete specimens (Bio) at different curing times $(1,7$, and 28$)$ days

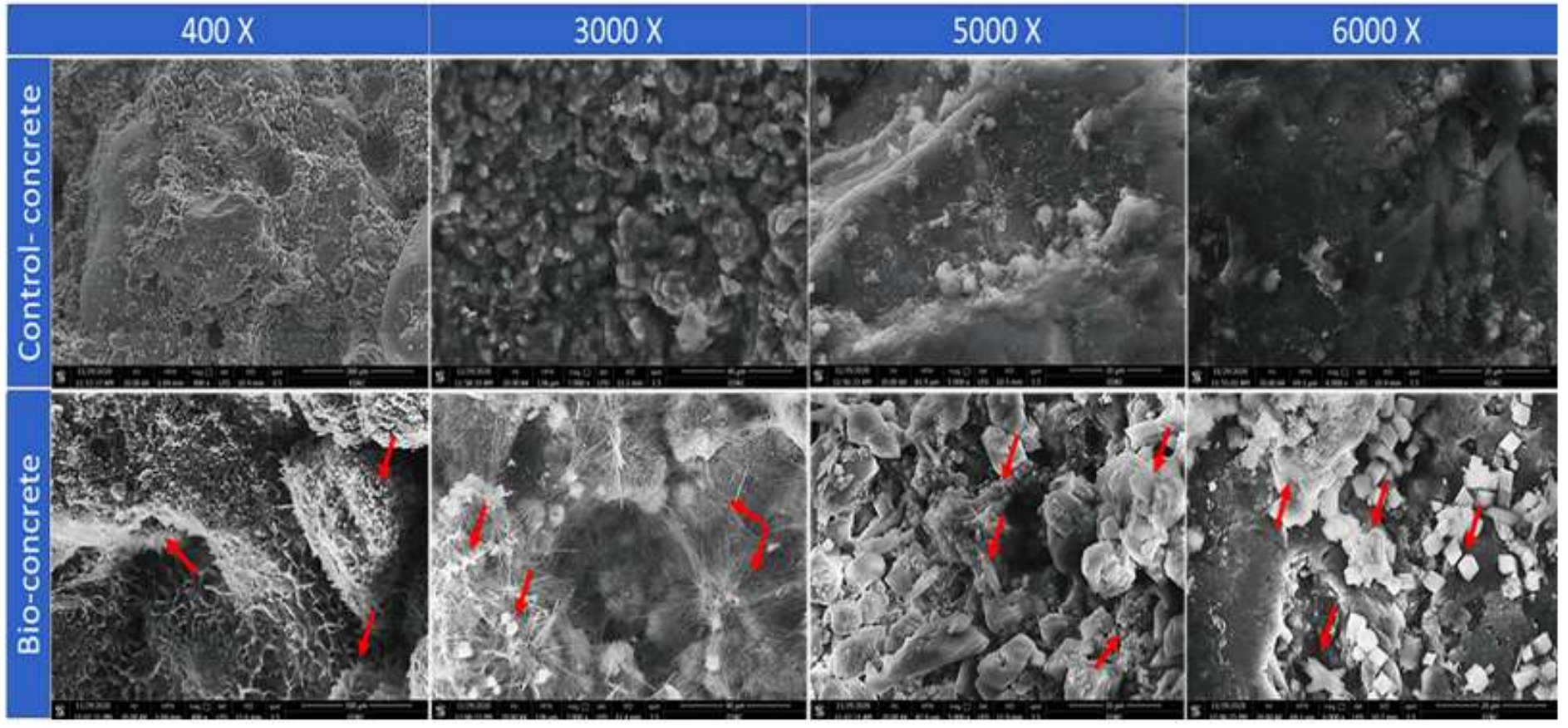

\section{Figure 8}

Scanning electron micrographs of bio-concrete and control specimens at 400, 3000, 5000, and 6000X. 


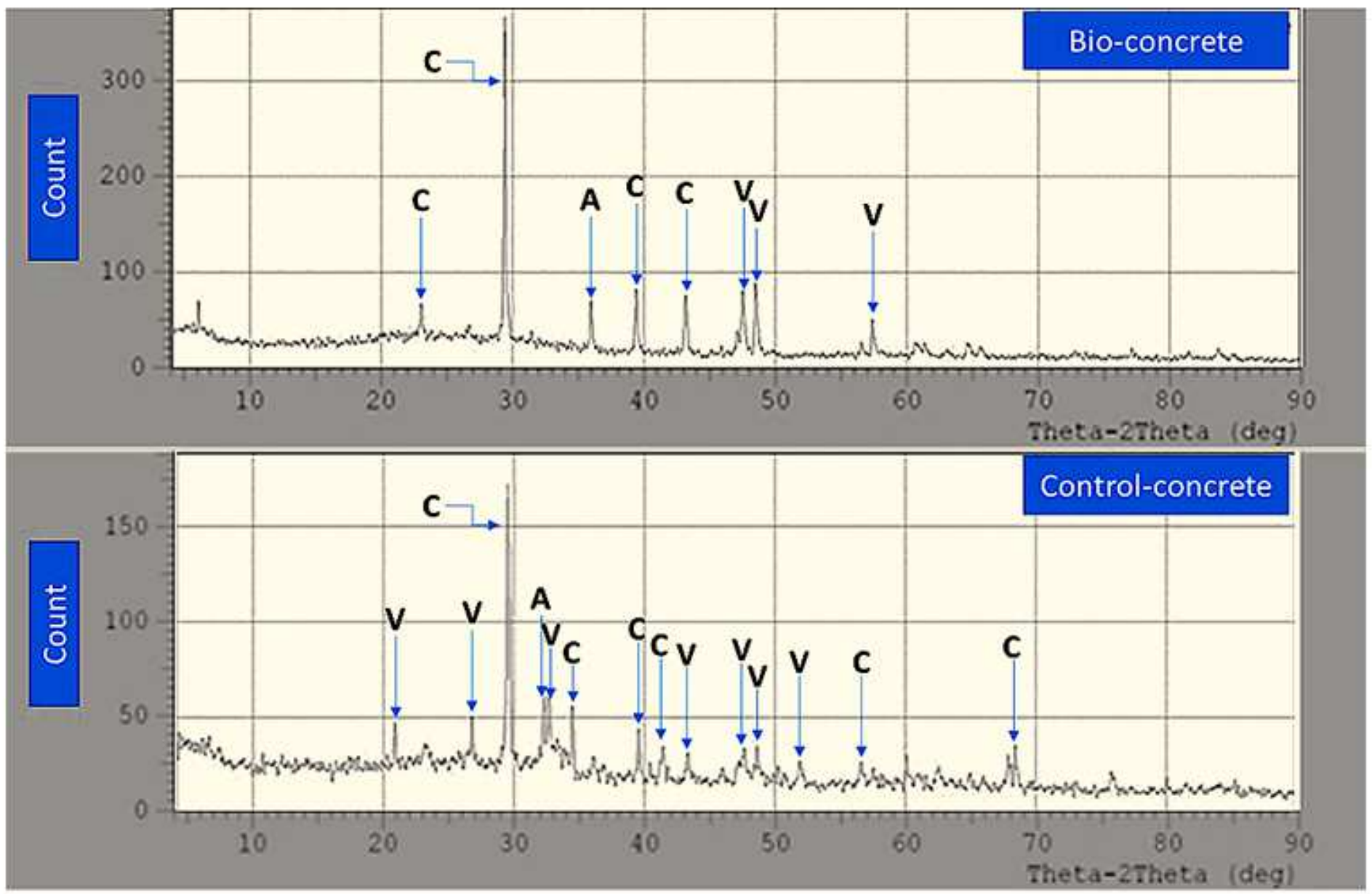

Figure 9

XRD patterns of bio-concrete and control-concrete specimens.

\section{Supplementary Files}

This is a list of supplementary files associated with this preprint. Click to download.

- graficalabstract.docx 